anales de psicología / annals of psychology

2019, vol. 35, nº 1 (january), 140-147

http://dx.doi.org/10.6018/analesps.35.1.301611
(C) Copyright 2019: Editum. Servicio de Publicaciones de la Universidad de Murcia. Murcia (Spain) ISSN print edition: 0212-9728. ISSN on line edition (http://revistas.um.es/analesps): 1695-2294.

On line edition License Creative Commons 4.0: BY-NC-ND

\title{
Habits and behaviours related to the health in adolescents during their leisure time
}

\author{
Pedro Gil-Madrona ${ }^{1}$, Alejandro Prieto-Ayuso ${ }^{1 *}$, Sheila Aparecida Dos Santos Silva ${ }^{2}$, Jaime Serra-Olivares ${ }^{1,3}$, \\ Miguel Ángel Aguilar Jurado ${ }^{1}$, and Arturo Díaz-Suárez ${ }^{4}$ \\ 1 Universidad de Castilla-La Mancha. Department of Music, Arts and Physical Education Pedagogy. Albacete (Spain) \\ 2 Universidade São Judas Tadeu. Programa de Posgrado en Educación Física. (Brasil) \\ 3 Catholic University of Temuco. Faculty of Education. Pedagogy in Physical Education. (Chile) \\ 4 University of Murcia. Departamento de Actividad Fisica y Deporte. (Spain)
}

\begin{abstract}
Título: Hábitos y comportamientos relacionados con la salud en adolescentes durante su tiempo libre.

Resumen: Esta investigación intenta determinar cuáles son las prácticas comunes relacionadas con la participación en actividades deportivas y físicas dentro del consumo de sustancias nocivas en adolescentes. Se realizó un diseño descriptivo, correlacional y transversal. Un total de 1.140 sujetos participaron en el estudio (Edad media: $18.75 \pm 6.35$ años; sexo: $46.7 \%$ masculino; $53.3 \%$ femenino), de los cuales 790 eran estudiantes universitarios y 350 no universitarios de la comunidad autónoma de Castilla-La Mancha (España). Se utilizó el Cuestionario de Evaluación de los Hábitos Relacionados con la Salud (Gil-Madrona, González-Víllora, Pastor-Vicedo, y Fernández-Bustos, 2010). El análisis descriptivo reveló que un alto porcentaje de adolescentes no practica deporte regularmente. El análisis diferencial mostró valores estadísticos significativos que relacionan el hábito deportivo con el consumo de tabaco, alcohol y/o drogas. Se concluyó que el diseño y desarrollo de programas que fomentan la actividad física son una necesidad.

Palabras clave: Salud; Actividad de ocio; Educación; Consumidor; Narcótico (Tesauro de la UNESCO).
\end{abstract}

\section{Introduction}

The changes produced in the concept of health modifies the way it is understood. Whilst some decades ago such a term was defined as the absence of disease, nowadays it is understood as the complete physical, mental and social well-being (WHO, 2006). According with Pastor-Vicedo, Gil-Madrona, Prieto-Ayuso and González-Villora (2015), although the recent definition is more complete than the previous one, the concept of health provides two well differentiated aspects. One of them, the less positive, embraces the concept as perfection when highlights a complete state of well-being marked by optimum physical, mental and social dimensions. With regard to this definition, very few people would be considered as healthy. The other aspect, more positive, is the integration of the concept in different dimensions, very often isolated. This makes necessary to know more about the living conditions of the people and their habits in order to understand, in this way, their health condition.

Health has increased his importance in the society. One of the indicators is the inclusion of this content in the school curriculum through the subject of Physical Education. At the

* Correspondence address [Dirección para correspondencia]: Alejandro Prieto-Ayuso. University of Castilla-La Mancha. Departamento de Didáctica de la Expresión Musical, Plástica y Corporal. Faculty of Education. Albacete. Plaza de la Universidad, 3. 02071. Albacete, Albacete (Spain). E-mail: Alejandro.Prieto@uclm.es

(Article received: 3-8-2017; revised: 22-1-2018; accepted: 19-2-2018)
Abstract: This research attempts to determine which are the common practices related to the participation in sport and physical activities within the consumption of harmful substances in adolescents. A descriptive, correlational and transversal design was performed. A total of 1,140 subjects participated in the study (Mean age: $18.75 \pm 6.35$ years old; gender: male $46.7 \%$, female $53.3 \%$ ), of wich 790 were undergraduates and 350 nonundergraduates from the autonomous community of Castilla-La Mancha (Spain). It was used the Evaluation Questionnaire of the Habits related to the Health (Gil-Madrona, González-Víllora, Pastor-Vicedo, \& FernándezBustos, 2010). Descriptive analysis revealed that a high percentage of adolescents do not practice sport regularly. The differential analysis showed significant statistical values which relates the sport habit with the tobacco, alcohol and/or drugs consumption. It was concluded that the design and development of programmes which foster physical activity are a need.

Keywords: Health; Leisure activity; Education; Consumer; Narcotic (UNESCO Thesaurus). beginning of the XIX century, health in the curriculum was based on hygienist purposes due to the industrialization process in which the society was immersed. Later, at the end of the XIX century and the beginning of the XX, the health promotion became truly important according to the great therapeutic potential of gymnastics.

In relation with the topic of this study, there exist works about healthy habits in adolescents and young from 12 to 25 years old, as the below mentioned and related with the promotion of health development (Ovideo et al., 2013), identification of physical activity patterns (Al-Hazzaa et al., 2014; López, González, \& Díaz, 2016), prevention of chronic disorders, as Abarca-Sos, Zaragoza, Generelo and Julián (2010), De Araújo et al. (2008), Calmeiro and Matos (2007), Junior et al. (2010), Cordente, García, Sillero and Domínguez (2007), and Piñeros and Pardo (2010), relation between the habit of exercising during the childhood and the adolescence and an active life during the adulthood (Azevedo, Araújo, Da Silva, \& Hallal, 2007), or obesity and its relation with nutritional habits or the physical inactivity, as Al-Hazzaa, Abahussain, Al-Sobayel, Qahwaji and Musaiger (2011), CárdenasCárdenas et al. (2015), De Pinho, De Botelho and Caldeira (2014), Flabe et al. (2014), Gouveia, Pereia-da Silva, Virella, Silva and Amaral (2007), Mariscal et al. (2015), Von PostSkagegård et al. (2002), among others.

Regarding the tobacco consumption, the research carried out by Ruiz-Juan Isorna-Folgar, Ruiz-Risueño Abab and Vaquero-Cristobal (2014), found out that the tobacco con- 
sumption was higher between men in their adult life (from 31 to 61 years old), people with dependent children, individuals with a secondary or university education, people who have abandoned the sport practice, and those whose member of the family smoke or consume alcohol. The consumption is lower between those who have engaged in vigorous physical activity and people over 60 . Smoking among adolescents showed a tendency of high blood pressure and plasmatic lipoprotein alterations twice as much as non-smokers (Guedes, Guedes, Barbosa, Oliveira, \& Stanganelli, 2006). The inverse relation between tobacco and sport activity was also registered in a research with 775 Brazilian adolescents where it was detected that the alcohol-consumer group shown the highest proportion of physical inactivity (Ceschini, Florindo, \& Benicio, 2007).

Another study carried out with 3,845 Brazilian adolescents brought about the association between physical inactivity and both tobacco and alcohol consumption (Ceschini, Andade, Oliveira, Araújo, Júnior, \& Matsudo, 2009). Among Spanish students there were no significant differences. The research carried out with 2,859 adolescents aged 13 to 18 showed that both males and females, if active, manifest a lower tobacco consumption (Tercedor et al., 2007). A study developed over 1,213 Afro-American girls and 1,166 NorthAmerican Caucasian girls aged 9-10 to 18-19, brought about the decline of physical activity of both groups as they got older. Furthermore, there was an increase of tobacco consumption by Caucasian girls when related to lower levels of physical activity (Kimm et al., 2002). Zurita and Álvaro (2014) analysed the levels of alcohol and tobacco consumption considering possible relations with academic and familiar influences. A total of 2,134 adolescents participated in the research. The results showed that adolescents with familiar dysfunction presented high dependency to tobacco and alcohol consumption, as well as high rates of repetition in grade schooler.

The smoking habit also seemed to be associated with energetic drinks consumption (Ibrahim et al., 2014) in adolescents and young in South-Arabia. The culture in which young people is immersed can also be a factor related to the smoking habit. A total of $29 \%$ of 647 Arabian undergraduates aged 18-26, are regular smokers, even though $73 \%$ showed their concern about its negative consequences. The most influential factors of tobacco consumption are the company of other smokers of their same age and having smoking parents (Hasim, 2000).

Smoking parents have also created at home a favourable environment which foster the smoking habit in North American children. Living with smoking parents increases not only the prevalence of smoking traditional cigarettes, but also electronic ones. Both parents and adolescents believe that the last ones cause less health damage than the traditional cigarettes. But, according to the authors of this study, this is still not possible to verify due the lack of longitudinal research (Cardenas et al., 2015).
When it comes to university population, it is observable how this gap has been investigated in relation with the identification of their physical activity habits (Blasco, Cruz, Pintanet i Bassets, Capdevila, \& Valiente, 1996), smoking habits (Hasim, 2000), creation of smoking habits (Rozi, Butt, \& Akhtar, 2007), relation between the consumption of energetic drinks and smoking habits (Ibrahim et at., 2014), drugs consumption (Molina et al., 2012), nutritional habits (Marcondelli, Costa, \& Schmitz, 2008; Sakamai, Toyama, Amamoto, Lui, \& Shinfuky, 2005; Yahia, Achkar, Abdallah, \& Rizk, 2008), energetic food and physical inactivity (Hall, Ochoa, \& Muñiz, 2014), unhealthy nutritional habits (Silliman, Rodas-Fortier, \& Neyman, 2004; Younis, 2014), and the time invested in physical activity (Silliman et al, 2004). In Spain, a total of 720 undergraduates from Galicia completed a questionnaire whose results showed that $78.3 \%$ of the students consume alcohol, 31.7\%, tobacco and 34\% has consumed illegal drugs at any time. Women consume less illegal drugs and alcohol, nevertheless, the continuous consumption is higher in women. This study shows that living with friends is a risk factor of legal-and-illegal-drug consumption. Sport, health and education undergraduates showed a lower prevalence on consumption drugs (Molina et al., 2012). Therefore, the tobacco consumption and other kind of drugs are related with the adoption of a sedentary lifestyle (Guillén, Roth, Alfaro, \& Fernández, 2015; Zamarripa, Ruiz, López, \& Fernández, 2013). For this reason, Marques, Martins, Sarmento, Rocha and Da Costa (2015) argued that strategies must be put into practice in order to foster physical activity among adolescents.

It is true that, even though there has been a slightly increase in physical activity over the last years, we are still far from the international recommendations (Ramos, JiménezIglesias, Rivera, \& Moreno, 2016). For that reason, this study aims to know which the common practices and routines of adolescents are. And secondly, to show the relationship with the consumption of harmful substances in three age groups (17-19, 20-23 and 24-25 years old) and gender. Finally, this study also analyses the frequency of these routines during the week or at the weekend.

\section{Method}

\section{Design}

A transversal and descriptive design was performed. The relation between physical activity and consumption of tobacco, alcohol and drugs among adolescents was analysed.

\section{Participants}

A purposive snowbal. sampling was carried out (Anguera, 2003). A total of 1,140 participants took part in the study (mean age: $18.75 \pm 6.35$ years old; gender: male $46.7 \%$, female $53.3 \%$ ), of which 790 were undegraduates and 350 non- 
undergraduates from the autonomous community of Castilla-La Mancha (Spain).

\section{Instrument}

The Evaluation Questionnaire of the Habits related to the Health (Gil-Madrona, González-Villora, Pastor-Vicedo, \& Fernández-Bustos, 2010) was used. It is an adapted instrument from the questionnaires Child and adolescent trial for cardiovascular bealth (CATCH) (Perry et al., 1990), Self-report measures of children's physical activity (SAPA) (Sallis, 1991). Moreover, it was considered the studies of Rodríguez and Agulló (1999), Rodríguez and Agulló (2003), Muñoz-Rivas, Navarro and Ortega (2003), García, Gómez and Ruiz (2005) and Míguez and Becoña (2015).

The structure of the questionnaire was confirmed by 20 qualitative items with multiple response, organised in 5 constructs or blocks about habits related to health: 1) Leisure time devotion; 2) Physical activity habits; 3) Alcohol consumption habits; 4) Drugs consumption habits; 5) Tobacco consumption habits. In the same way, the questionnaire presented some questions related to their age and gender.

Regarding the reliability of the instrument, Alpha of Cronbanch was performed $(\alpha=0.88$, IC 95\% $=[0.864$; $0.893])$. It confirms its reliability. Regarding the validity, given the qualitative nature of the items, content validity was carried out (Escobar-Pérez and Cuervo-Martínez, 2008). For this purpose, 7 well-known experts were selected (two research periods). The experts carried out an individual assessment using the Likert validation questionnaire (with 3 points: $1=$ low; $2=$ average; $3=$ high). Then they evaluated the sections and gave a global assessment (high (3) $=85.3 \%$ ), adequacy (high $(3)=79,8 \%$ ), precision (high $(3)=73.2 \%$ ) and relevance (high $(3)=74.8 \%$ ) for each of the blocks or constructs in which the instrument was divided. Subsequently, a comparative assessment of expert accordance was held with a Kappa concordance coefficient of $((x=0.78$; IC $95 \%$ $=[0.762 ; 0.795])$. The conclusions showed accordance among experts. Albeit some modifications related to the items were done by the experts. These were fully considered.

\section{Procedure}

A total of five collaborators, trained in a research seminar, distributed the questionnaire related to health habits among the participants in the surroundings of the different university campuses of University of Castilla-La Mancha (Albacete, Ciudad Real, Cuenca and Toledo). The questionnaire was administered by a researcher who asked personally to individuals. This questionnaire was preceded by an explanatory letter which included the aims of the research, an informed consent, a declaration of its non-committal nature, the confidentiality implied, the realization of a non-invasive test and the e-mail of the referral researchers. Every participant completed an independent questionnaire in the month of January 2017. Next, the data was analysed according to the different categories of the questionnaire about physical activity habits and tobacco, alcohol and/or drugs consumption. The Ethical Committee of the University of Castilla-La Mancha approved this research.

\section{Statistical analysis}

Firstly, data collected was filtered and analysed searching for possible mistakes, outliers and irrelevant data for the investigation. Once filtered, a statistical analysis of the data was carried out in two sections: (1) Descriptive analysis and (2) inferential analysis. The descriptive analysis was based on frequencies and percentages, obtaining a global vision of the data for each one of the categories. Then, it was performed a more specific vision by segmenting with a cross-classification both variables gender and age.

The inferential analysis, due to the qualitative nature of the variables, was based on Pearson Chi-squared and the likelihood ratio tests, both related to non-parametric tests. The intensity of statistical associations was measured with the contingency coefficient. The statistical analysis was carried out with the statistical programme SPSS v.22.0. using a confidence interval of $95 \%$.

\section{Results}

\section{Descriptive analysis}

The descriptive analysis revealed a high percentage of participants who do not regularly practice physical activity (table 1), with a total of $73 \%$ (nearly $40 \%$ of the female participants and $25 \%$ of male participants). Regarding the weekly hours invested in physical activity, $58.8 \%$ of those who practiced sport (regardless the gender) affirmed to invest less than four hours a day, and the $76.8 \%$ less than four hours at the weekend. Regarding the tobacco, alcohol and/or drugs consumption (table 2), the descriptive analysis revealed that $23.5 \%$ of the participants smokes regularly (regardless the gender) of which $50.4 \%$ consumes more than cigarettes 10 a day and struggle to avoid smoking in forbidden places $(40.6 \%)$. Regarding the consumption of alcohol (table 3 ), $35 \%$ of participants claim to consume it occasionally during the week, being males the main consumers in terms of frequency $(19.3 \%)$. It must be highlighted that $34.2 \%$ of the participants declare consuming alcohol at the weekends and "drinking too much" or even "losing control", being males the gender which presents the higher frequency (22.2\%). Equally, 20-30\% of the participants affirm "go boozing up", this is drink in the street, every weekend (25.6\%), twice a month $(28.3 \%)$, less than once a month $(23 \%)$ or hardly ever $(23.1 \%)$. These findings highlight bad habits related to health. Regarding drugs consumption (table 4), it should be emphasised that near $53.7 \%$ of participants has ever consumed "cannabis", "cocaine" or "ecstasy" at some point. In this sense, $31.1 \%$ of participants consumes drugs regularly during the week and the $19.3 \%$ at the weekend. 
Table 1. Physical activity habits according to the age and gender of the participants (percentages).

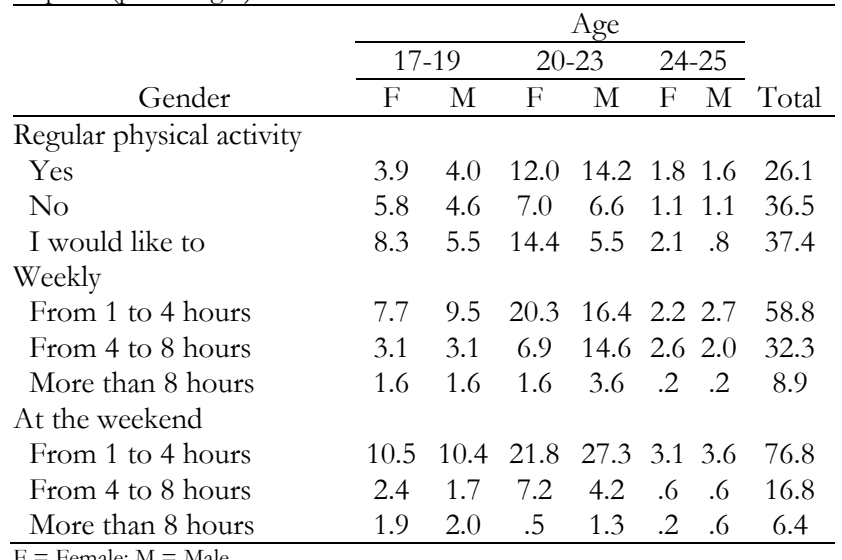

Table 2. Tobacco consumption habits according to the age and gender of the participants (percentages).

\begin{tabular}{|c|c|c|c|c|c|c|c|}
\hline \multirow[b]{3}{*}{ Gender } & \multicolumn{6}{|c|}{ Age } & \multirow[b]{3}{*}{ Total } \\
\hline & \multicolumn{2}{|c|}{$17-19$} & \multicolumn{2}{|c|}{$20-23$} & \multicolumn{2}{|c|}{$24-25$} & \\
\hline & $\mathrm{F}$ & $\mathrm{M}$ & $\mathrm{F}$ & $\mathrm{M}$ & $\mathrm{F}$ & $\mathrm{M}$ & \\
\hline \multicolumn{8}{|l|}{ Smoker } \\
\hline Yes & 4.0 & 4.1 & 7.5 & 5.8 & 1.1 & 1.0 & 23.5 \\
\hline No & 12.8 & 11.6 & 24.2 & 21.0 & 3.8 & 3.2 & 76.5 \\
\hline \multicolumn{8}{|l|}{ Daily cigarettes } \\
\hline More than 30 & 1.4 & .7 & 2.1 & 1.4 & .0 & .0 & 5.6 \\
\hline $21-30$ & 3.5 & 3.1 & 5.9 & 6.3 & .7 & .3 & 19.8 \\
\hline $11-20$ & 3.1 & 6.9 & 6.6 & 5.2 & 1.4 & 1.7 & 25.0 \\
\hline Less than 11 & 8.3 & 7.6 & 16.7 & 11.1 & 2.8 & 3.1 & 49.7 \\
\hline \multicolumn{8}{|c|}{ Struggling to avoid smoking in forbidden places } \\
\hline Yes & 9.0 & 7.5 & $12.3^{1}$ & 8.0 & 1.9 & 1.9 & 40.6 \\
\hline No & 9.0 & 9.0 & 20.3 & 14.2 & 3.3 & 3.8 & 59.4 \\
\hline
\end{tabular}

Table 3. Alcohol consumption habits according to the age and gender of the participants (percentages).

\begin{tabular}{|c|c|c|c|c|c|c|c|}
\hline \multirow[b]{3}{*}{ Gender } & \multicolumn{6}{|c|}{ Age } & \multirow[b]{3}{*}{ Total } \\
\hline & \multicolumn{2}{|c|}{$17-19$} & \multicolumn{2}{|c|}{$20-23$} & \multicolumn{2}{|c|}{$24-25$} & \\
\hline & $\mathrm{F}$ & $\mathrm{M}$ & $\mathrm{F}$ & $\mathrm{M}$ & $\mathrm{F}$ & $\bar{M}$ & \\
\hline \multicolumn{8}{|l|}{ During the week } \\
\hline Never & 9.5 & 7.5 & 22.0 & 13.6 & 2.9 & 2.5 & 58.0 \\
\hline Occasionally & 5.0 & 5.7 & 8.9 & 12.1 & 1.8 & 1.5 & 35.0 \\
\hline Frequently & .5 & 1.2 & 2.8 & 1.5 & .4 & .5 & 7.0 \\
\hline \multicolumn{8}{|l|}{ At the weekend } \\
\hline Nothing & 4.0 & 2.3 & 6.4 & 3.9 & 1.8 & 1.4 & 19.8 \\
\hline With moderation & 8.5 & 6.0 & 18.6 & 10.5 & 1.5 & 1.0 & 46.0 \\
\hline Sometimes too much & 2.1 & 2.5 & 5.0 & 6.9 & .8 & 1.1 & 18.4 \\
\hline I lose control & 1.7 & 4.6 & 2.0 & 5.9 & .6 & 1.2 & 15.8 \\
\hline \multicolumn{8}{|l|}{ Drink in the street } \\
\hline Every weekend & 4.1 & 6.3 & 5.5 & 8.0 & 1.0 & .8 & 25.6 \\
\hline Twice a month & 5.7 & 3.1 & 9.9 & 7.4 & 1.2 & 1.0 & 28.3 \\
\hline At least once a month & 2.3 & 2.2 & 9.5 & 6.7 & 1.0 & 1.2 & 23.0 \\
\hline Never or hardly ever & 4.8 & 3.9 & 6.9 & 4.7 & 1.6 & 1.2 & 23.1 \\
\hline
\end{tabular}

Table 4. Drug consumption habits according to the age and gender of the participants (percentages).

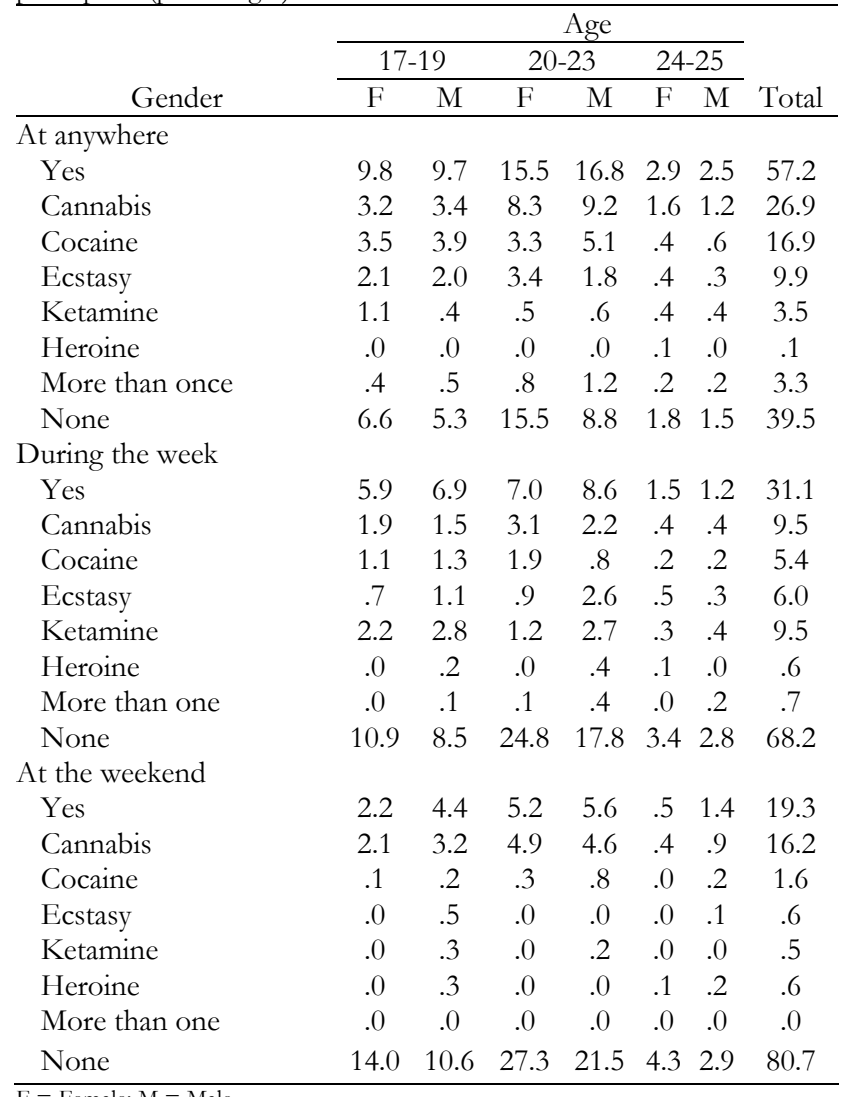

$\mathrm{F}=$ Female; $\mathrm{M}=$ Male

\section{Inferential Analysis}

The inferential analysis revealed that there existed significant relationships between physical activity habits and those related to the consumption tobacco, alcohol and/or drugs. Regarding the consumption of tobacco, it can be observed in table 5 that exists a significant relation between the variable "smoker" and the frequency of the "regular practice of physical activity" (0.003), and between the "daily quantity of cigarettes" and the "regular practice of physical activity" (0.022). Regarding the consumption of alcohol, in the table 6 can be observed the relationship between the "consumption during the week" and the "regular practice of physical activity" $(0.000)$, as well as the relation between the "frequency of drink in the street" and the "regular practice of physical activity" (0.000), which marked a significant relation. Finally, regarding drugs consumption (table 7 ), the relationship between "consumption at the weekend" and "regular practice of physical activity" (0.000) showed significative values. 
Table 5. Relationship between physical activity habits and tobacco consumption (Chi: Chi Square; Likelihood ratio; p: value of p; C: contingency coefficient)

\begin{tabular}{lcccc}
\hline & & $\begin{array}{c}\text { Regular } \\
\text { Physical } \\
\text { Activity }\end{array}$ & $\begin{array}{c}\text { Some } \\
\text { hours } \\
\text { a week }\end{array}$ & $\begin{array}{c}\text { Some hours } \\
\text { at the } \\
\text { Weekend }\end{array}$ \\
\hline Smoker & Chi & 11.531 & 3.842 & 4.156 \\
& C & $.003 * *$ & .146 & .125 \\
Daily tobacco & Chi / RV & 0.106 & 0.083 & 0.080 \\
consumer & $p$ & $.022^{*}$ & .272 & .136 \\
Struggling to & $\mathrm{C}$ & 0.255 & 0.236 & 0.246 \\
avoid smoking in & Chi / RV & 1.704 & 3.803 & 5.232 \\
forbidden places & $\mathrm{C}$ & .427 & .149 & .073 \\
$*=$ Sig. $5 \%$ & & 0.105 & 0.195 & 0.211 \\
** = Sig. $1 \%$ & & & &
\end{tabular}

Table 6. Relationship between physical activity habits and alcohol consumption (Chi: Chi Square; Likelihood ratio; p: value of p; C: contingency coefficient)

\begin{tabular}{lcccc}
\hline & & $\begin{array}{c}\text { Regular } \\
\text { Physical } \\
\text { Activity }\end{array}$ & $\begin{array}{c}\text { Some } \\
\text { hours } \\
\text { a week }\end{array}$ & $\begin{array}{c}\text { Some hours } \\
\text { at the } \\
\text { Weekend }\end{array}$ \\
\hline \multirow{3}{*}{ During the week } & Chi & 39.871 & 6.796 & 5.744 \\
& $p$ & $.000^{* *}$ & .147 & .219 \\
At the Weekend & C & 0.216 & 0.115 & 0.104 \\
& Chi & 125.943 & 18.265 & 77.230 \\
Drink in the street & C & $.000^{* *}$ & $.006^{* *}$ & $.000^{* *}$ \\
& Chi & 76.439 & 0.182 & 0.341 \\
& C & $.000^{* *}$ & .5958 & 8.203 \\
& 0.265 & 0.091 & .224 \\
\hline
\end{tabular}

$*=$ Sig. $5 \%$

$* *=\operatorname{Sig} .1 \%$

Table 7. Relationship between physical activity habits and drugs consumption (Chi: Chi Square; Likelihood ratio; p: value of p; C: contingency coefficient).

\begin{tabular}{lcccc}
\hline & & $\begin{array}{c}\text { Regular } \\
\text { Physical } \\
\text { Activity }\end{array}$ & $\begin{array}{c}\text { Some } \\
\text { hours } \\
\text { a week }\end{array}$ & $\begin{array}{c}\text { Some hours } \\
\text { at the } \\
\text { Weekend }\end{array}$ \\
\hline Occasional drugs & Chi & 113.989 & 12.796 & 39.954 \\
& C & $.000^{* *}$ & $.012^{*}$ & $.000^{* *}$ \\
Regular drugs & RV & 264.575 & 0.150 & 0.241 \\
consumption & $p$ & $.000^{* *}$ & $.000^{* *}$ & $.000^{* *}$ \\
during the week & $\mathrm{C}$ & 0.431 & 0.187 & 0.303 \\
Regular drugs & $\mathrm{Chi}$ & 18.250 & 1.238 & 68.114 \\
consumption at & $p$ & $.000^{* *}$ & .539 & $.000^{* *}$ \\
the weekend & $\mathrm{C}$ & 0.136 & 0.048 & 0.315 \\
\hline * = Sig. 5\% & & & & \\
$* *=$ Sig. $1 \%$ & & & &
\end{tabular}

\section{Discussion}

The aim of this research has been to determine the relationship between the physical activity habits and the consumption of harmful substances in a group of adolescents. The results show a high percentage of undergraduates who do not exercise regularly (around 70\%), and a high percentage of participants whose physical activity is lower than four hours a week. This finding matches with the results obtained in previous studies, as those of Ceschini et al. (2009), and Guedes and Grondin (2002). Derived from the results, it is highlighted the need to foster physical activity programmes to improve the heath habits (Marques et al., 2015).

Regarding to tobacco, alcohol and/or drugs consumption habits, the observed results are quite negative according to the high rate of cigarette consumption. This can explain why the participants practice less physical activity than other previous studies as Guillén et al. (2015), Kimm et al. (2002) and Zamarripa et al. (2013). In this way, the relation between tobacco consumption and physical activities was observed.

Regarding the percentages observed in both alcohol and drugs consumption, the findings are similar. Therefore, it can be highlighted the importance of creating awareness about this correlation during the school, with the purpose to reduce the consumption of these harmful substances among children and increase the quantity of physical activity practice. Previous studies (Guillén et al., 2015; Zamarripa et al., 2013) have demonstrated a relationship between the consumption of alcohol or other type of drugs and the adoption of sedentary habits. Therefore, it should be emphasised in this study the relationship observed between physical activity practice and the consumption of tobacco, alcohol and/or drugs. In this sense, it is highlighted the need to carry our intervention programmes about addictions and levels of physical activity. For example, it must be highlighted the intervention programme of Martínez-Martínez, Contreras-Jordán, Lera-Navarro and Aznar-Laín (2010). Their aim was to measure physical activity in children and identify how much healthy physical activity is performed in and outside of a school context in a week, using accelerometers. The results obtained showed that the participants did not follow the recommendations proposed by the World Health Organization (WHO, 2010). The physical activity quantity held during a week in Physical Education classes represented a significant quantity. According to these results, it is necessary the implementation of programmes which supplement Physical Education classes, because it seems to be insufficient in order to reach the recommendation settled by the World Health Organization (WHO, 2010).

Nevertheless, not only it is important to highlight the implementation of programmes, but also their assessment in order to prove whether these programmes have reached their purposes in terms of efficacy and efficiency (Garcés \& Díaz, 2013). They stress the importance of not only the development of these programmes, but also the design of assessment strategies. Likewise, the evaluation programmes should monitor the analysis of all variables (social, sport, familiar, personal, etc.) which may emphasize the execution of the objectives (physiological, physiological, technical, etc.). The observed results here mentioned mean an important finding for society, as they reflect the reality in relation to the physical activity habits and the drugs, alcohol and tobacco consumption in adolescents. According to Garces and Díaz (2013), other physical-sport programmes could be developed 
and assessed in many other areas, and not only with the purpose of health maintenance. Therefore, we can carry out programmes in any of these areas: physical activity for physically and/or psychologically disabled people, physical activity programmes for elderly people, or sport initiation programmes.

Therefore, this research highlights the relationship between to invest more time in physical activity and a minor consumption of harmful substances. In this sense, apart from the before-mentioned social benefits, this research contributes to the progress of the scientific community interested in the health field, as well as it updates the state of art already known. Moreover, it opens new investigation lines related to the practice of physical activity and the tobacco, alcohol and drugs consumption. For example, studies as those carried out by Chau and Saravia (2016), Guzmán and Galaz (2015) and Brabete (2014) provide further information in this field of knowledge through the design and validation of instruments related to health behaviours in undergraduates.

\section{References}

Abarca-Sos, A., Zaragoza, J., Generelo, E., \& Julián, J. (2010). Comportamientos sedentarios y patrones de actividad física en adolescentes. International Journal of Medicine and Science of Physical Activity and Sport, 10(39), 410-427.

Al-Hazzaa, H. M., Abahussain, N. A., Al-Sobayel, H. I., Qahwaji, D. M., \& Musaiger, A. O. (2011). Physical activity, sedentary behaviors and dietary habits among Saudi adolescents relative to age, gender and region. International Journal of Behavioral Nutrition and Physical Activity, 8(1), 1-14.

Al-Hazzaa, H. M., Alahmadi, M. A., Al-Sobayel, H. I., Abahussain, N. A., Qahwaji, D. M., \& Musaiger, A. O. (2014). Patterns and determinants of physical activity among saudi adolescents. Journal of physical activity $y$ bealth, 11(6), 1202-11. doi: 10.1123/jpah.20120427

Anguera, M. T. (2003). La observación. In C. Moreno Rosset (Ed.), Evaluación psicológica. Concepto, proceso y aplicación en las áreas del desarrollo y de la inteligencia (pp. 271-308). Madrid: Sanz y Torres.

Azevedo, M. R., Araújo, C. L., Da Silva, M. C., \& Hallal, P. C. (2007). Tracking of physical activity from adolescence to adulthood: a population-based study. Revista de Saúde Pública, 41(1), 69-75.

Beatriz, S. S., Frandsen, L. E., Paixão, G., \& Lanes, R. C. (2006). Associação entre estado nutricional e atividade física em escolares da Rede Municipal de Ensino em Corumbá-MS. Revista Brasileira de Medicina do Esporte, 12(2), 90-94. doi: 10.1590/S151786922006000200007

Blasco, T., Cruz, J., Pintanel i Bassets, M., Capdevila, L., \& Valiente, L. (1996). Evolución de los patrones de actividad física en estudiantes universitarios. Revista de Psicología del Deporte, 5(2), 51-63.

Brabete, A. C. (2014). El Cuestionario de Salud General de 12 items (GHQ-12): estudio de traduccion y adaptacion de la version rumana. Revista Iberoamericana de diagnóstico y Evaluación -e Avaliaçao Psicológica. RIDEP, 37(1), 9-27.

Caballero, C., Hernández, B., Moreno, H., Hernández-Girón, C., Campero, L., Cruz, A., \& Lazcano-Ponce, E. (2007). Obesidad, actividad e inactividad física en adolescentes de Morelos, México: un estudio longitudinal. Archivos Latinoamericanos de Nutrición, 57(3), 231.

Calmeiro, L., \& Matos, M. (2007). Efectos del programa de gestión personal en la promoción de la actividad física en adolescentes. Revista de Psicología del Deporte, 8(1), 87-101.
It should be mentioned that one limitation of the study was the low sampling size with regards to the study population. Notwithstanding, the sample is representative of the adolescent population of the autonomous community of Castilla-La Mancha. It makes evident the fact that the findings reveal a regional problem which should be confirmed in a national research.

Nonetheless, it can be concluded that there exists a relationship between the low level of physical activity practice in adolescents and the consumption of harmful substances here mentioned: alcohol, tobacco and drugs. On the other side, it is highlighted the need to develop programmes which foster the physical activity practice at both school and university context to increase activity levels, as well as their assessment to prove their effectiveness.

Conflict of interests.- The authors of this article declare that there are no conflicts of interest.

Cárdenas-Cárdenas, L. M., Burguete-Garcia, A. I., Estrada-Velasco, B. I., López-Islas, C., Peralta-Romero, J., Cruz, M., \& Galván-Portillo, M. (2015). Leisure-time physical activity and cardiometabolic risk among children and adolescents. Jornal de pediatria, 91(2), 136-142. doi: 10.1016/j.jped.2014.06.005

Cardenas, V. M., Breen, P. J., Compadre, C. M., Delongchamp, R. R., Barone, C. P., Phillips, M. M., \& Wheeler, J. G. (2015). The smoking habits of the family influence the uptake of e-cigarettes in US children. Annals of epidemiology, 25(1), 60-62. ddoi: 10.1016/j.annepidem.2014.09.013

Ceschini, F., Andrade, D. R., Oliveira, L. C., Araújo Júnior, J. F., \& Matsudo, V. K. (2009). Prevalência de inatividade física e fatores associados em estudantes do ensino médio de escolas públicas estaduais. Jornal de pediatria, 85(4), 301-306. doi: 10.1590/S002175572009000400006

Ceschini, F. L., Florindo, A. A., \& Benicio, M. H. (2007). Nível de atividade física em adolescentes de uma regiao de elevado índice de vulnerabilidade juvenil. Revista Brasileira de Ciência e Movimento, 15(4), 67-78

Cordente, C. A., García, P., Sillero, M., \& Domínguez, J. (2007). Relación del nivel de actividad física, presión arterial y adiposidad corporal en adolescentes madrileños. Revista española de salud pública, 81(3), 307-317.

Chau, C., \& Saravia, J. C. (2016). Conductas de Salud en Estudiantes Universitarios Limeños: Validación del CEVJU. Revista Iberoamericana de diagnóstico y Evaluación -e Avaliaçao Psicológica. RIDEP, 41(1), 90-103.

De Araújo, T. L., De Oliveira, M. V., Cavalcante, T. F., Guedes, N. G., Moreira, R. P., Chaves, E. S., y Da Silva, V. M. (2008). Análise de indicadores de risco para hipertensão arterial em crianças e adolescentes. Revista da Escola de Enfermagem da USP, 42(1), 120-126. doi: 10.1590/S0080-62342008000100016

De Pinho, L., De Botelho, A. C., \& Caldeira, A. P. (2014). Associated factors of overweight in adolescents from public schools in Northern Minas Gerais State, Brazil. Revista Paulista de Pediatria, 32(2), 237-243. doi: 10.1590/0103-0582201432216213

Falbe, J., Willett, W. C., Rosner, B., Gortmaker, S. L., Sonneville, K. R., \& Field, A. E. (2014). Longitudinal relations of television, electronic games, and digital versatile discs with changes in diet in 
adolescents. The American journal of clinical nutrition, 100(4), 11731181. doi: $10.3945 /$ ajcn.114.088500

Garcés, E., \& Díaz, A. (2013). Diseño y desarrollo de programas de actividad física y deportiva. Madrid: Ediciones Díaz de Santos.

García, M. E., Gómez, M., \& Ruiz, F. (2005). Hábitos FísicosDeportivos en centros Escolares y Universitarios: Madrid, Gymnos.

Gil-Madrona, P., González-Villora, S., Pastor-Vicedo, J. C., \& Fernández-Bustos, J. G. (2010). Actividad física y hábitos relacionados con la salud en los jóvenes: estudio en España. Reflexiones, 89(2), 147-161.

Gouveia, C., Pereira-da-Silva, L., Virella, D., Silva, P., \& Amaral, J. M. V. (2007). Actividade física e sedentarismo em adolescentes escolarizados do concelho de Lisboa. Acta Pediatrica Portuguesa, 38(1), 7-12.

Guedes, D. P., \& Grondin, L. M. V. (2002). Percepção de hábitos saudáveis por adolescentes: associação com indicadores alimentares, prática de atividade física e controle de peso corporal. Revista brasileira de Ciências do Esporte, 24(1).

Guedes, D. P., Guedes, J., Barbosa, D. S., Oliveira, J. D., \& Stanganelli, L. C. R. (2006). Fatores de risco cardiovasculares em adolescentes: indicadores biológicos e comportamentais. Arquivos Brasileiros de Cardiologia, 86(6), 439-450. 10.1590/S0066782X2006000600006

Guillén, N., Roth, E., Alfaro, A., \& Fernández, E. (2015). Youth alcohol drinking behavior: Associated risk and protective factors. Revista Iberoamericana de Psicología y Salud, 6(2), 53-63. doi: 10.1016/j.rips.2015.03.001

Guzmán, M. L. B., \& Galaz, M. M. F. (2015). Construcción de una Escala de Salud Mental Positiva para Adultos en Poblacion Mexicana. Revista Iberoamericana de diagnóstico - e Avaliaģao psicológica. RIDEP, 39(1), 22-33.

Hall, J. A., Ochoa, P. Y., \& Muñiz, J. (2014). Nivel de Actividad Física en estudiantes de la Universidad de Colima. Revista de Educación, Motricidad e Investigación(2), 1-6

Hasim, T. (2000). Smoking habits of students in College of Applied Medical Science, Saudi Arabia. Saudi Medical Journal, 21(1), 76-80.

Hernández, R., Fernández, C., \& Baptista, P. (2006). Metodología de la investigación. México.

Ibrahim, N. K. R., Iftikhar, R., Murad, M., Fida, H., Abalkhaeil, B., \& Al Ahmadi, J. (2014). Energy drinks consumption amongst medical students and interns from three colleges in Jeddah, Saudi Arabia. Journal of Food and Nutrition Research, 2(4), 174-179. doi: 10.12691/jfnr-2-4-7

Junior, R. W., Vilarouca, A. R., Moura, M. F., Pessoa, N. B., Coelho, M. M., \& Oliveira, M. R. (2010). Physical activity practice by adolescents from Fortaleza. Revista Brasileira de Enfermagem, 63(3), $410-415$.

Kimm, S. Y., Glynn, N. W., Kriska, A. M., Barton, B. A., Kronsberg, S. S., Daniels, S. R., . . L Liu, K. (2002). Decline in physical activity in black girls and white girls during adolescence. New England Journal of Medicine, 347(10), 709-715. 10.1056/NEJMoa003277

López, G. F., González, S., \& Díaz, A. (2016). Level of habitual physical activity in children and adolescents from the Region of Murcia (Spain). SpringerPlus, 5:386, 1-6. doi: 10.1186/s40064-0162033-8

Marcondelli, P., Costa, T. H., \& Schmitz, B. (2008). Nível de atividade física e hábitos alimentares de universitários do $3^{\circ}$ ao $5^{\circ}$ semestres da área da saúde. Revista de Nutrição, 21(1), 39-47. doi: 10.1590/S1415-52732008000100005

Mariscal, M., Monteagudo, C., Hernandez-Elizondo, J., Benhammou, S., Lorenzo, M. L., \& Olea, F. (2015). Differences in food intake and nutritional habits between Spanish adolescents who engage in ski activity and those who do not. Nutrición Hospitalaria, 31(2), 936943. doi: 10.3305/nh.2015.31.2.8267.
Marques, A., Martins, J., Sarmento, H., Rocha, L., \& da Costa, F. C. (2015). Do students know the physical activity recommendations for health promotion? Journal of Physical Activity and Health, 12, 253256. doi: 10.1123/ipah.2013-0228

Martínez-Martínez, J., Contreras-Jordán, O. R., Lera-Navarro, Á., \& Aznar-Laín, S. (2012). Niveles de actividad física medido con acelerómetro en alumnos de $3^{\circ}$ ciclo de educación primaria: actividad física diaria y sesiones de educación física. Revista de Psicologia del Deporte, 21(1), 117-123.

Míguez, M. C., \& Becoña, E. (2015). ¿El consumo de cigarrillos y alcohol se relaciona con el consumo de cánnabis y el juego problema en adolescentes españoles? Adicciones, 27(1), 8-16.

Molina, A. J., Varela, V., Fernández, T., Martín, V., Ayán, C., \& Cancela, J. M. (2012). Hábitos no saludables y práctica de actividad física en estudiantes universitarios españoles: papel del género, perfil académico y convivencia. Adicciones, 24(4), 319-327.

Muñoz-Rivas, M. J., navarro, M. P., \& Ortega, N. (2003). Patrones de uso de Internet en población universitaria española. Adicciones, 15(2), 137-144.

Oviedo, G., Sánchez, J., Castro, R., Calvo, M., Sevilla, J. C., Iglesias, A., \& Guerra, M. (2013). Niveles de actividad física en población adolescente: estudio de caso. Retos: nuevas tendencias en educación física, deporte y recreación, 23, 43-47.

Pastor-Vicedo, J. C., Gil-Madrona, P., Prieto-Ayuso, A., \& GonzálezVíllora, S. (2015). Los contenidos de salud en el área de educación física: Análisis del currículum vigente. Retos: nuevas tendencias en educación fisica, deporte y recreación(28), 134-140.

Perry, C. L., Stone, E. J., Parcel, G. S., Ellison, R. C., Nader, P. R., Webber, L. S., \& Luepker, R. V. (1990). School-based cardiovascular health promotion: The child and adolescent trial for cardiovascular health (CATCH). Journal of School Health, 60(8), 406413.

Piñeros, M., \& Pardo, C. (2010). Actividad física en adolescentes de cinco ciudades colombianas: resultados de la Encuesta Mundial de Salud a Escolares. Revista de Salud pública, 12(6), 903-914.

Ramos, P., Jiménez-Iglesias, A., Rivera, F., \& Moreno, C. (2016). Evolución de la práctica de la actividad física en los adolescentes españoles/Physical Activity Trends in Spanish Adolescents. Revista Internacional de Medicina y Ciencias de la Actividad Física y del Deporte, 16(62), 335-353.

Rodríguez , J., \& Agulló, E. (1999). Estilos de vida, cultura, ocio y tiempo libre de los estudiantes universitarios. Psicothema, 11(2), 247 259.

Rodríguez, J., Agulló, E., \& Agulló, M. S. (2003). Jóvenes, fin de semana y uso recreativo de drogas: evolución y tendencias del ocio juvenil. Adicciones, 15(5), 7-34.

Rodríguez, P. L. (2006). La promoción de la salud desde el entorno educativo. In P. L. Rodríguez garcía (Ed.), Educación Física y salud en Primaria (pp. 39-72). Zaragoza: INDE.

Rozi, S., Butt, Z. A., \& Akhtar, S. (2007). Correlates of cigarette smoking among male college students in Karachi, Pakistan. BMC Public Health, 7(1), 1-8. doi: 10.1186/1471-2458-7-312

Ruiz-Juan, F., Isorna-Folgar, M., Ruiz-Risueño Abad, J. R., \& VaqueroCristobal, R. (2014). Consumo de tabaco en adultos el sureste español y su relación con la actividad físico-deportiva y familia. Retos: nuevas tendencias en educación física, deporte y recreación(26), 27-33.

Sakamaki, R., Toyama, K., Amamoto, R., Liu, C. J., \& Shinfuku, N. (2005). Nutritional knowledge, food habits and health attitude of Chinese university students-a cross sectional study-. Nutrition Journal, 4(1), 1. doi: 10.1186/1475-2891-4-4

Sallis, J. F. (1991). Self-report measures of children's physical activity. Journal of School Health, 61 (5), 215-219.

Silliman, K., Rodas-Fortier, K., \& Neyman, M. (2004). A survey of dietary and exercise habits and perceived barriers to following a 
healthy lifestyle in a college population. Californian Journal of Health Promotion, 18, 281.

Tercedor, P., Martín-Matillas, M., Chillón, P., Pérez López, I., Ortega, F., Wärnberg, J., ... Delgado, M. (2007). Incremento del consumo de tabaco y disminución del nivel de práctica de actividad física en adolescentes españoles: Estudio AVENA. Nutrición Hospitalaria, 22(1), 89-94.

Von Post-Skagegård, M., Samuelson, G., Karlström, B., Mohsen, R., Berglund, L., \& Bratteby, L. (2002). Changes in food habits in healthy Swedish adolescents during the transition from adolescence to adulthood. European journal of clinical nutrition, 56, 532-538. doi: 10.1038/sj.ejcn.1601345
WHO. (2006). Constitución de la Organización Mundial de la Salud. Documentos básicos.

WHO. (2010). Recomendaciones mundiales sobre actividad fisica para la salud.

Yahia, N., Achkar, A., Abdallah, A., \& Rizk, S. (2008). Nutritional habits and obesity among Lebanese university students. Nutrition Journal, 7(1), 1. doi: 10.1186/1475-2891-7-32

Zamarripa, J. I., Ruiz, F., López, J. M., \& Fernández, R. (2013). Actividad e inactividad física durante el tiempo libre en la población adulta de Monterrey (Nuevo León, México). Retos: nuevas tendencias en educación física, deporte y recreación (24), 91-96.

Zurita, F., \& Álvaro, J. I. (2014). Repercusión del tabaco y alcohol sobre factores académicos y familiares en adolescentes. Health and Addictions, 14(1), 59-70. 